\title{
COXEN Score 23
}

National Cancer Institute

\section{Source}

National Cancer Institute. COXEN Score 23. NCI Thesaurus. Code C128220.

A score of 23 on the COXEN Sensitivity Scale. 